\title{
Thermal behavior of metallic and fiber cement tiles with simple and double layers
}

\author{
Eduardo Alves Almeida - Fernando Augusto de Souza • \\ Renato Luis Furlan • José Eduardo Pitelli Turco - Adhemar Pitelli Milani
}

\author{
EA Almeida (Corresponding author) - FA Souza • RL \\ Furlan \\ Department of Morphology and Animal Physiology, São \\ Paulo State University, 14884-900, Jaboticabal, SP, Brazil. \\ email: eng.eduardoalves@hotmail.com
}

Received: December 18, 2017 • Revised: February 11, 2018 • Accepted: February 14, 2018

\begin{abstract}
This research was conducted aiming to evaluate the thermal behavior of metallic and fiber cement tiles installed in simple and double layers. The experiment was performed on prototypes of roofing in single layers and double-spaced from 1.0 to $5.0 \mathrm{~cm}$. It was used temperature sensors, installed on the inner surface of the roofing and in the center of the model for data collection. Data were analyzed using Skott-Knott test, considering the time of day, and roof type. The results showed that the spacing between tiles has an important influence on temperature gradient inside the prototype, been observed that double-spaced roofs, with $5.0 \mathrm{~cm}$, showed the best results for metallic and fiber cement tiles.
\end{abstract}

Keywords: ambience, building material, thermal efficiency, thermal insulation

\section{Introduction}

The roof is responsible for absorbing and transmits the large part of the energy from the solar radiation to the interior of the buildings increasing the thermal gains (Michels 2007). According to Sampaio et al (2011), in not shaded areas, the temperature variation tend to follow the local climate, while inside the premises, coverage tends to mitigate the temperature variations and does not allow the occurrence of abruptly thermal fluctuation. Amongst the roof characteristics that influence the thermal environment, there are the tile material, surface area and the existence and effectiveness of thermal insulation and liners (Damasceno 2008; Conceição et al 2008; Dias 2011). For Curtis (1983), the ideal material for covering must have high reflectivity and thermal emissivity on the top surface, and low solar reflectivity and thermal emissivity in the inner surface.

According to Akbari et al (2005) the temperature of the roof's inner surface is directly related to the heat conduction to the interior of the building. According to Faghih and Bahadori
(2010), the solar energy absorbed by the roof promotes an increase in your temperature, and this energy is transmitted to the inside of the building, causing air heating. There are several ways that can be used in order to dispel the solar energy received by the roof, such as the use of reflective paint (Almeida and Passini 2013), use of liners (Smith et al 2015), insulation layers (Canepelle et al 2013), etc.

In livestock production, high temperatures influence negatively the performance and wellbeing. According to several studies, heat stress can negatively impact production traits, including meat and egg quality, reproductive performance, intestinal functions and the immune response (Fouad et al 2016, Tan et al 2010; Song et al 2014; Wang et al 2016). Considering the importance of cover materials on the inner temperature of the buildings, it was conducted a trial with the aim to evaluate the thermal behavior of metal and fiber cement tiles, installed with simple and double layers.

\section{Materials and Methods}

The study was carried in the Department of Rural Engineering located in FCAV / Unesp Jaboticabal, 21 ${ }^{\circ} 15^{\prime 2} 22^{\prime \prime}$ $\mathrm{S}$ latitude and $48^{\circ} 18^{\prime} 58^{\prime \prime} \mathrm{W}$ longitude, $595 \mathrm{~m}$ of altitude. The climate, based on Köppen classification, is the Awa type, described as the dry tropical in winter, with dry season (April to September) and concentration of rainfall in the summer months (October to March).

It was used metallic tiles and fiber cement tiles, with a thickness of $0.06 \mathrm{~cm}$ and $0.50 \mathrm{~cm}$, respectively, being installed with single and double layers, with space between the layers ranging from 1 to $5 \mathrm{~cm}(1,2,3,4$ and $5 \mathrm{~cm})$. The tiles were installed on prototypes, made of styrofoam boxes, with the thickness of $10.0 \mathrm{~cm}$, and internal dimensions of $34.0 \times 74.1 \mathrm{x}$ $55.3 \mathrm{~cm}$. The spaces between the prototype and the roofing were filled with polystyrene foam. 
The prototypes were placed on concrete platform, with dimensions of $150 \times 150 \mathrm{~cm}$, disposed of in a free shade place. The experiment was composed of 12 treatments, tiles $\mathrm{x}$ spacing (Table 1), with two prototypes for each treatment. It was adopted as repetition the day and the number of prototypes, with the total of 30 repetitions for each treatment ( 2 prototypes x 15 measurement days).
The thermal behavior of the tiles was evaluated through the measurement of internal prototype temperature, obtained with the aid of thermocouples type T, model $105 \mathrm{~T}$, positioned in the internal surface of the tile (IST) and the geometric center of the prototype (IT). Data collection was done hourly, between the months of May to August 2013, with the aid of a data logger CAMPBELL SCIENTIFIC-INC.

Table 1 Experimental treatments.

\begin{tabular}{cl} 
MS & Metal tile (single layer) \\
MD1 & Metal tile with spacing of $1.0 \mathrm{~cm}$ between layers (Double layer) \\
MD2 & Metal tile with spacing of $2.0 \mathrm{~cm}$ between layers (Double layer) \\
MD3 & Metal tile with spacing of $3.0 \mathrm{~cm}$ between layers (Double layer) \\
MD4 & Metal tile with spacing of $4.0 \mathrm{~cm}$ between layers (Double layer) \\
MD5 & Metal tile with spacing of $5.0 \mathrm{~cm}$ between layers (Double layer) \\
FS & Fiber cement tile (Single layer) \\
FD1 & Fiber cement tile with spacing of $1.0 \mathrm{~cm}$ between layers (Double layer) \\
FD2 & Fiber cement tile with spacing of $2.0 \mathrm{~cm}$ between layers (Double layer) \\
FD3 & Fiber cement tile with spacing of $3.0 \mathrm{~cm}$ between layers (Double layer) \\
FD4 & Fiber cement tile with spacing of $4.0 \mathrm{~cm}$ between layers (Double layer) \\
FD5 & Fiber cement tile with spacing of $5.0 \mathrm{~cm}$ between layers (Double layer) \\
\hline
\end{tabular}

For analysis, It was used the PROC MIXED of SAS (Statistical Analysis System), with repeated measurements over time, considering the measurement hours for each evaluated days, being carried out analysis of variance and Scott-Knott test for comparison of averages at $1 \%$ significance level.

\section{Results and Discussion}

It was verified that the inner surface temperature (IST) of both roofs followed the same pattern (Table 2), with the lowest values in the early hours of the day, reaching the maximum value between $12 \mathrm{~h}$ and $14 \mathrm{~h}$ (period with maximum solar radiation), and then decreasing at the end of the day. Similar behavior was observed by Fiorelli et al. (2012), who have found the higher temperature at $14 \mathrm{~h}$. Almeida and Passini (2013), studied different types of roofing and also checked an increase in the air temperature, reaching the peak at $14 \mathrm{~h}$ and decreasing thereafter.

The use of double layers promoted significant IST decrease for both roof types, being observed values significantly lower than the single layer at $14 \mathrm{~h}\left(42.9^{\circ} \mathrm{C}\right.$ vs. $31.6^{\circ} \mathrm{C}$, for $\mathrm{MS}$ and $\mathrm{MD} 5$, respectively) and $39.3^{\circ} \mathrm{C}$ vs. $31.7^{\circ} \mathrm{C}$, for FS and FD5, respectively. This fact shows the efficiency of the double-layer tiles, where the air between the two layers acts as thermal insulator, preventing that part of the solar energy could be transferred to the internal surface of the cover. When we compare the two types of the roof (metallic and fiber cement) installed in single layers, it is verified lower
IST $\left(39.3^{\circ} \mathrm{C}\right)$ for fiber cement tiles than metal tiles $\left(42.9^{\circ} \mathrm{C}\right)$, being this result in line with several studies.

Abreu et al (2011) observed lower IST for fiber cement tiles in relation to metallic tiles at $14 \mathrm{~h}$. Fonseca et al. (2011) also verified similar results when studying fiber cement tiles and zinc tiles, where fiber cement tile presented better thermal efficiency than the metallic tile studied (zinc). Sampaio et al. (2011) studied the superficial temperature of roofing and their relation to the building thermal environment. The authors' verified that metallic tiles exceeded $53^{\circ} \mathrm{C}$ on the surface, being observed the worst results for this type of roof when compared with the other studied materials (cement and clay).

Regarding the use of double-layers, it was observed highly effective of this system in reducing the IST. At 14:00 hours, It was observed for metallic tiles the following values for IST: $\mathrm{MS}\left(42.9^{\circ} \mathrm{C}\right)$, MD1 $\left(35.0^{\circ} \mathrm{C}\right), \mathrm{MD} 2\left(32.9^{\circ} \mathrm{C}\right), \mathrm{MD} 3$ $\left(32.7^{\circ} \mathrm{C}\right)$, MD4 $\left(31.8^{\circ} \mathrm{C}\right)$ and MD5 $(31.60 \mathrm{C})$, being verified that the greater the spacement between layers, less is the IST. About fiber cement tiles, it was observed lower IST for the treatments FD4 $(32.9 \mathrm{oC})$ and FD5 $\left(31.7^{\circ} \mathrm{C}\right)$, and the highest value in $\mathrm{FS}\left(39.3^{\circ} \mathrm{C}\right)$, whereas the other treatments had intermediate IST values (FD1 $\left(35.3^{\circ} \mathrm{C}\right), \mathrm{FD} 2\left(34.3^{\circ} \mathrm{C}\right)$ and FD3 $\left(33.7^{\circ} \mathrm{C}\right)$ ). According to Abreu et al. (2011), it is important to highlight that the roof temperature decrease does not mean thermal comfort to the animals, being important to measure the thermal load of radiation that achieves the animals in each situation. 
Table 2 Internal Surface Temperature (IST) for the different treatments and schedules.

\begin{tabular}{|c|c|c|c|c|c|c|c|c|c|c|c|c|}
\hline$\overline{\mathrm{H}}$ & MS & MD1 & MD2 & MD3 & MD4 & MD5 & FS & FD1 & FD2 & FD3 & FD4 & FD5 \\
\hline 8 & $21.2^{\mathrm{aA}}$ & $20.1^{\mathrm{aA}}$ & $21.2^{\mathrm{aA}}$ & $20.9^{\mathrm{aA}}$ & $21.4^{\mathrm{aA}}$ & $21.4^{\mathrm{aA}}$ & $21.7^{\mathrm{aA}}$ & $20.5^{\mathrm{aA}}$ & $20.3^{\mathrm{aA}}$ & $20.1^{\mathrm{aA}}$ & $20.1^{\mathrm{aA}}$ & $20.5^{\mathrm{aA}}$ \\
\hline 9 & $30.0^{\mathrm{dB}}$ & $26.1^{\mathrm{bC}}$ & $25.6^{\mathrm{bC}}$ & $24.8^{\mathrm{bC}}$ & $24.4^{\mathrm{aB}}$ & $24.5^{\mathrm{aB}}$ & $27.5^{\mathrm{aB}}$ & $24.9^{\mathrm{bB}}$ & $24.2^{\mathrm{aB}}$ & $23.5^{\mathrm{aB}}$ & $23.2^{\mathrm{aB}}$ & $23.5^{\mathrm{aB}}$ \\
\hline 10 & $37.0^{\mathrm{dD}}$ & $29.8^{\mathrm{bD}}$ & $29.1^{\mathrm{bD}}$ & $28.7^{\mathrm{bD}}$ & $27.4^{\mathrm{aC}}$ & $27.5^{\mathrm{aC}}$ & $33.4^{\mathrm{cD}}$ & $28.9^{\mathrm{bC}}$ & $28.1^{\mathrm{aC}}$ & $27.3^{\mathrm{aC}}$ & $27.3^{\mathrm{aC}}$ & $26.6^{\mathrm{aC}}$ \\
\hline 11 & $39.1^{\mathrm{eE}}$ & $32.0^{\mathrm{cE}}$ & $30.9^{\mathrm{cE}}$ & $30.3^{\mathrm{bE}}$ & $28.9^{\mathrm{aD}}$ & $29.0^{\mathrm{aD}}$ & $37.1^{\mathrm{dE}}$ & $32.2^{\mathrm{cD}}$ & $31.1^{\mathrm{cE}}$ & $30.1^{\mathrm{bD}}$ & $30.0^{\mathrm{bD}}$ & $28.7^{\mathrm{aD}}$ \\
\hline 12 & $43.4^{\mathrm{eG}}$ & $34.7^{\mathrm{dF}}$ & $33.2^{\mathrm{cF}}$ & $32.3^{\mathrm{bF}}$ & $30.8^{\mathrm{aE}}$ & $30.8^{\mathrm{aE}}$ & $40.5^{\mathrm{eF}}$ & $35.0^{\mathrm{dE}}$ & $33.6^{\mathrm{cF}}$ & $32.4^{\mathrm{bE}}$ & $32.6^{\mathrm{bE}}$ & $30.6^{\mathrm{aE}}$ \\
\hline 13 & $41.5^{\mathrm{dF}}$ & $34.9^{\mathrm{cF}}$ & $33.3^{\mathrm{bF}}$ & $32.6^{\mathrm{aF}}$ & $31.2^{\mathrm{aE}}$ & $31.2^{\mathrm{aE}}$ & $40.5^{\mathrm{dF}}$ & $36.1^{\mathrm{cE}}$ & $34.9^{\mathrm{cG}}$ & $33.4^{\mathrm{bE}}$ & $33.7^{\mathrm{bF}}$ & $31.5^{\mathrm{aE}}$ \\
\hline 14 & $42.9^{\mathrm{dG}}$ & $35.0^{\mathrm{bF}}$ & $32.9^{\mathrm{aF}}$ & $32.7^{\mathrm{aF}}$ & $31.8^{\mathrm{aE}}$ & $31.6^{\mathrm{aE}}$ & $39.3^{\mathrm{cF}}$ & $35.3^{\mathrm{bE}}$ & $34.3^{\mathrm{bG}}$ & $33.7^{\mathrm{bE}}$ & $32.9^{\mathrm{aF}}$ & $31.7^{\mathrm{aE}}$ \\
\hline 15 & $38.1^{\mathrm{eE}}$ & $33.6^{\mathrm{bF}}$ & $32.3^{\mathrm{bF}}$ & $31.7^{\mathrm{aF}}$ & $30.8^{\mathrm{aE}}$ & $30.6^{\mathrm{aE}}$ & $36.1^{\mathrm{dE}}$ & $34.2^{\mathrm{cE}}$ & $33.2^{\mathrm{cF}}$ & $32.3^{\mathrm{bE}}$ & $32.6^{\mathrm{bE}}$ & $31.0^{\mathrm{aE}}$ \\
\hline 16 & $34.3^{\mathrm{cC}}$ & $32.3^{\mathrm{bE}}$ & $31.4^{\mathrm{aE}}$ & $31.0^{\mathrm{aE}}$ & $30.5^{\mathrm{aE}}$ & $30.2^{\mathrm{aE}}$ & $33.1^{\mathrm{bD}}$ & $33.0^{\mathrm{bD}}$ & $32.3^{\mathrm{bF}}$ & $31.5^{\mathrm{aE}}$ & $32.0^{\mathrm{bE}}$ & $30.5^{\mathrm{aE}}$ \\
\hline 17 & $30.2^{\mathrm{aB}}$ & $29.9^{\mathrm{aD}}$ & $29.5^{\mathrm{aD}}$ & $29.3^{\mathrm{aD}}$ & $28.9^{\mathrm{aD}}$ & $28.8^{\mathrm{aD}}$ & $28.9^{\mathrm{cC}}$ & $29.9^{\mathrm{aC}}$ & $29.6^{\mathrm{aD}}$ & $29.2^{\mathrm{aD}}$ & $29.5^{\mathrm{aD}}$ & $28.8^{\mathrm{aD}}$ \\
\hline 18 & $21.2^{\mathrm{aA}}$ & $22.6^{\mathrm{bB}}$ & $22.7^{\mathrm{bB}}$ & $22.6^{\mathrm{aB}}$ & $22.5^{\mathrm{aA}}$ & $22.4^{\mathrm{aA}}$ & $21.3^{\mathrm{aA}}$ & $24.4^{\mathrm{cB}}$ & $24.3^{\mathrm{cB}}$ & $24.2^{\mathrm{cB}}$ & $24.1^{\mathrm{cB}}$ & $23.4^{\mathrm{aB}}$ \\
\hline
\end{tabular}

$\mathrm{H}=$ period of the day (hours); MS= Metallic tile (single layer); MD1=metallic tile (double layer) spaced 1cm; MD2=metallic tile (double layer) spaced 2cm; MD3=metallic tile (double layer) spaced 3cm; MD4=metallic tile (double layer) spaced 4cm; MD5=metallic tile (double layer) spaced 5cm; FS=Fiber ciment tile (single layer); FS1=Fiber ciment tile (double layer) spaced 1cm; FS2=Fiber ciment (double layer) spaced 2cm; FS3=Fiber ciment tile (double layer) spaced $3 \mathrm{~cm}$; FS4=Fiber ciment tile (double layer) spaced $4 \mathrm{~cm}$; FS5=Fiber ciment tile (double layer) spaced $5 \mathrm{~cm}$.

* Different lowercase letters indicate significant differences in line for Skott-Knott test at $1 \%$ significance level.

** Different capital letters indicate significant differences in the column by Skott-Knott test at $1 \%$ significance

Table 3 Internal Temperature (IT) for the different treatments throughout the day.

\begin{tabular}{ccccccccccccc}
\hline $\mathrm{H}$ & $\mathrm{MS}$ & $\mathrm{MD} 1$ & $\mathrm{MD} 2$ & $\mathrm{MD} 3$ & $\mathrm{MD} 4$ & $\mathrm{MD}$ & $\mathrm{FS}$ & FD & FD & FD & FD & FD \\
\hline 8 & $21.4^{\mathrm{bA}}$ & $21.3^{\mathrm{bA}}$ & $21.8^{\mathrm{bA}}$ & $21.6^{\mathrm{bA}}$ & $22.0^{\mathrm{bA}}$ & $22.0^{\mathrm{bA}}$ & $21.0^{\mathrm{aA}}$ & $20.8^{\mathrm{aA}}$ & $20.6^{\mathrm{aA}}$ & $20.7^{\mathrm{aA}}$ & $20.6^{\mathrm{aA}}$ & $20.7^{\mathrm{aA}}$ \\
9 & $26.7^{\mathrm{dC}}$ & $24.8^{\mathrm{bC}}$ & $24.7^{\mathrm{bC}}$ & $24.4^{\mathrm{bC}}$ & $24.4^{\mathrm{bC}}$ & $24.5^{\mathrm{bC}}$ & $25.3^{\mathrm{cB}}$ & $24.1^{\mathrm{bB}}$ & $23.7^{\mathrm{aB}}$ & $23.6^{\mathrm{aB}}$ & $23.4^{\mathrm{aB}}$ & $23.5^{\mathrm{aB}}$ \\
10 & $31.7^{\mathrm{dE}}$ & $28.1^{\mathrm{bD}}$ & $27.6^{\mathrm{bD}}$ & $27.4^{\mathrm{bD}}$ & $27.1^{\mathrm{aD}}$ & $27.1^{\mathrm{aD}}$ & $29.9^{\mathrm{cD}}$ & $27.5^{\mathrm{bC}}$ & $26.9^{\mathrm{aC}}$ & $26.9^{\mathrm{aC}}$ & $26.7^{\mathrm{aC}}$ & $26.4^{\mathrm{aC}}$ \\
11 & $33.5^{\mathrm{cF}}$ & $29.8^{\mathrm{bE}}$ & $29.1^{\mathrm{aE}}$ & $28.8^{\mathrm{aE}}$ & $28.5^{\mathrm{aE}}$ & $28.5^{\mathrm{aE}}$ & $32.9^{\mathrm{cF}}$ & $30.0^{\mathrm{bE}}$ & $28.9^{\mathrm{aD}}$ & $28.9^{\mathrm{aD}}$ & $28.9^{\mathrm{aD}}$ & $28.1^{\mathrm{aD}}$ \\
12 & $35.9^{\mathrm{dG}}$ & $31.6^{\mathrm{cF}}$ & $30.7^{\mathrm{bF}}$ & $30.2^{\mathrm{aF}}$ & $30.0^{\mathrm{aF}}$ & $29.9^{\mathrm{aF}}$ & $35.6^{\mathrm{dG}}$ & $32.2^{\mathrm{cG}}$ & $30.9^{\mathrm{bE}}$ & $30.8^{\mathrm{bE}}$ & $30.9^{\mathrm{bE}}$ & $29.8^{\mathrm{aE}}$ \\
13 & $35.8^{\mathrm{dG}}$ & $32.3^{\mathrm{cG}}$ & $31.3^{\mathrm{aF}}$ & $30.8^{\mathrm{aF}}$ & $30.1^{\mathrm{aF}}$ & $30.4^{\mathrm{aF}}$ & $35.8^{\mathrm{dG}}$ & $32.9^{\mathrm{cG}}$ & $31.7^{\mathrm{bF}}$ & $31.6^{\mathrm{bE}}$ & $31.7^{\mathrm{bE}}$ & $30.6^{\mathrm{aE}}$ \\
14 & $36.1^{\mathrm{cG}}$ & $32.5^{\mathrm{bG}}$ & $31.5^{\mathrm{aF}}$ & $31.0^{\mathrm{aF}}$ & $31.0^{\mathrm{aF}}$ & $30.8^{\mathrm{aF}}$ & $35.4^{\mathrm{cG}}$ & $32.6^{\mathrm{bG}}$ & $31.8^{\mathrm{bF}}$ & $31.8^{\mathrm{bE}}$ & $31.6^{\mathrm{aE}}$ & $30.9^{\mathrm{aE}}$ \\
15 & $33.8^{\mathrm{cF}}$ & $31.4^{\mathrm{bF}}$ & $30.8^{\mathrm{bF}}$ & $30.3^{\mathrm{aF}}$ & $30.2^{\mathrm{aF}}$ & $30.0^{\mathrm{aF}}$ & $33.4^{\mathrm{cF}}$ & $31.9^{\mathrm{bF}}$ & $31.0^{\mathrm{bE}}$ & $31.0^{\mathrm{bE}}$ & $31.2^{\mathrm{bE}}$ & $30.2^{\mathrm{aE}}$ \\
16 & $32.3^{\mathrm{CE}}$ & $31.0^{\mathrm{bF}}$ & $30.6^{\mathrm{aF}}$ & $30.1^{\mathrm{aF}}$ & $30.1^{\mathrm{aF}}$ & $29.8^{\mathrm{aF}}$ & $31.6^{\mathrm{bE}}$ & $31.1^{\mathrm{bF}}$ & $30.4^{\mathrm{bE}}$ & $30.4^{\mathrm{aE}}$ & $30.8^{\mathrm{aE}}$ & $29.8^{\mathrm{aE}}$ \\
18 & $29.6^{\mathrm{aD}}$ & $29.1^{\mathrm{aE}}$ & $29.0^{\mathrm{aE}}$ & $28.6^{\mathrm{aE}}$ & $28.8^{\mathrm{aE}}$ & $28.5^{\mathrm{aE}}$ & $28.3^{\mathrm{aC}}$ & $28.9^{\mathrm{aD}}$ & $28.6^{\mathrm{bD}}$ & $28.7^{\mathrm{aD}}$ & $29.0^{\mathrm{aD}}$ & $28.3^{\mathrm{aD}}$ \\
\hline
\end{tabular}

$\mathrm{H}=$ period of the day (hours); MS= Metallic tile (single layer); MD1=metallic tile (double layer) spaced 1cm; MD2=metallic tile (double layer) spaced 2cm; MD3=metallic tile (double layer) spaced 3cm; MD4=metallic tile (double layer) spaced 4cm; MD5=metallic tile (double layer) spaced 5cm; FS=Fiber ciment tile (single layer); FS1=Fiber ciment tile (double layer) spaced 1cm; FS2=Fiber ciment (double layer) spaced 2cm; FS3=Fiber ciment tile (double layer) spaced $3 \mathrm{~cm}$; FS4=Fiber ciment tile (double layer) spaced $4 \mathrm{~cm}$; FS5=Fiber ciment tile (double layer) spaced $5 \mathrm{~cm}$.

* Different lowercase letters indicate significant differences in line for Skott-Knott test at $1 \%$ significance level.

** Different capital letters indicate significant differences in the column by Skott-Knott test at $1 \%$ significance

The average values for internal temperature (IT) (Table 3) followed the same pattern observed for IST, being observed at $14 \mathrm{~h}$ the higher IT values in the treatments where was used single layer than when were used double layers for both roof type (metallic and fiber ciment). It was observed that the use of single layers roofs (MS and FS) promoted an oscillation of $14.7{ }^{\circ} \mathrm{C}$ when was used metallic tile and $14.4{ }^{\circ} \mathrm{C}$ when was used fiber cement tile (considering the cooler hour (8h) and hottest hour (14h)), while the same coverage installed in double-layers with the spacement of $5 \mathrm{~cm}$ showed a variation of $8.8{ }^{\circ} \mathrm{C}$ (metallic tile) and $10.2{ }^{\circ} \mathrm{C}$ (fiber cement tile), showing that the use of double layers promotes a more stable environment with greater thermal inertia and smaller temperature variations.

A lower environmental temperature variation through the day it is positive to animal production since the animal thermoregulatory system tends to work with less energy expenditure, as well the machines used for the environmental temperature control will not be activated frequently. According to Guimarães et al. (2014), animals kept in environments with very wide temperature ranges may have their performance compromised, by the need to adapt the temperature variations, which may compromise the maintenance of their physiological indexes. Abreu et al. (2007) studying the performance of broiler chickens reared in 
aviaries with and without the presence of lining, and they verified that the presence of lining promotes lower thermal amplitudes and, consequently, better feed consumption and weight gain compared to the animals raised in the poultry barns without the liner.

It was observed that the use of double layers was effective in the reduction of the temperature in the different treatments, where the increase in the spacing between double layers (until $5 \mathrm{~cm}$ ) promotes a gradual decrease in the IT values. Metallic tiles showed better results when was used double layers, with significant lower IT values for MD2 $\left(31.5^{\circ} \mathrm{C}\right), \operatorname{MD} 3\left(31.0^{\circ} \mathrm{C}\right), \operatorname{MD} 4\left(31.0^{\circ} \mathrm{C}\right)$ and $\operatorname{MD} 5\left(30.8^{\circ} \mathrm{C}\right)$, being the highest value observed for $\mathrm{MS}\left(36.1^{\circ} \mathrm{C}\right)$, getting MD1 $\left(32.5^{\circ} \mathrm{C}\right)$ with an intermediate value. For fiber cement tiles, the lowest values were verified in the treatments FD4 $\left(31.6^{\circ} \mathrm{C}\right)$ and FD5 $\left(30.9^{\circ} \mathrm{C}\right)$, being the highest value observed for FS $\left(35.4^{\circ} \mathrm{C}\right)$, being observed intermediate values for FD1 $\left(326^{\circ} \mathrm{C}\right)$, FD2 $\left(31.8^{\circ} \mathrm{C}\right)$ and FD3 $\left(31.8^{\circ} \mathrm{C}\right)$. These results are in line with Caneppele et al (2013), who found lower environmental temperature and greater thermal inertia when used sandwich tile, with lower internal temperature fluctuations.

Days (2011) highlight that the use of sandwich tiles are extremely efficient in promoting better thermal environment in regions with a large daily temperature ranges, being able to reduce this thermal variation. This information is consistent with the result of this study, where the temperature range inside the prototype was lower when we're used double layers. Figure 1 shows the IST and IT values in the different treatments at $14 \mathrm{~h}$.

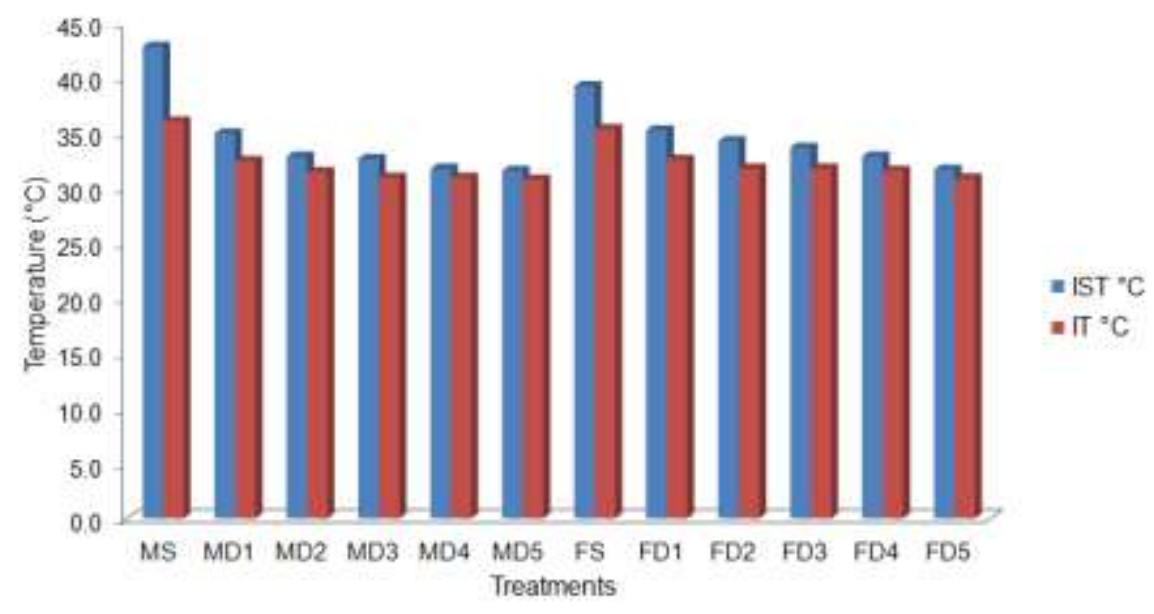

Figure 1 Relationship between IST and IT in the different treatments.
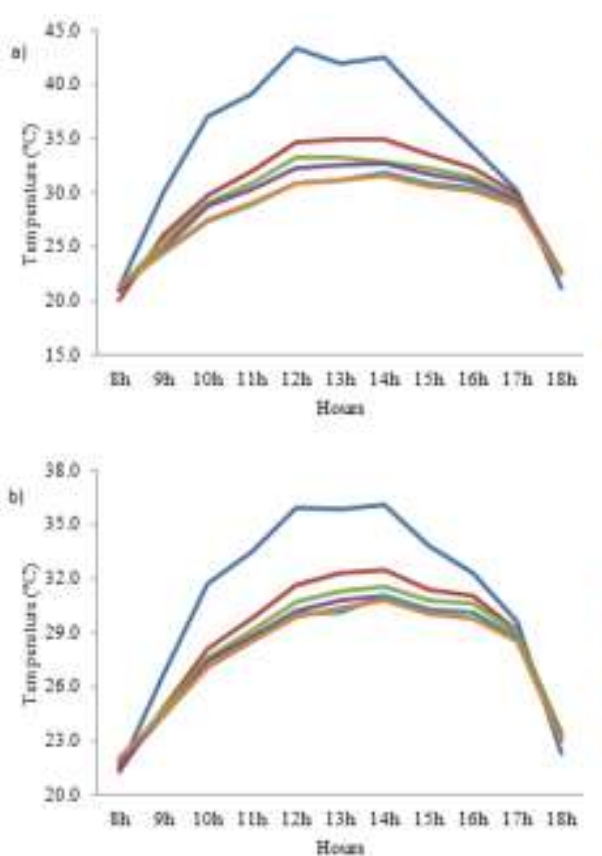
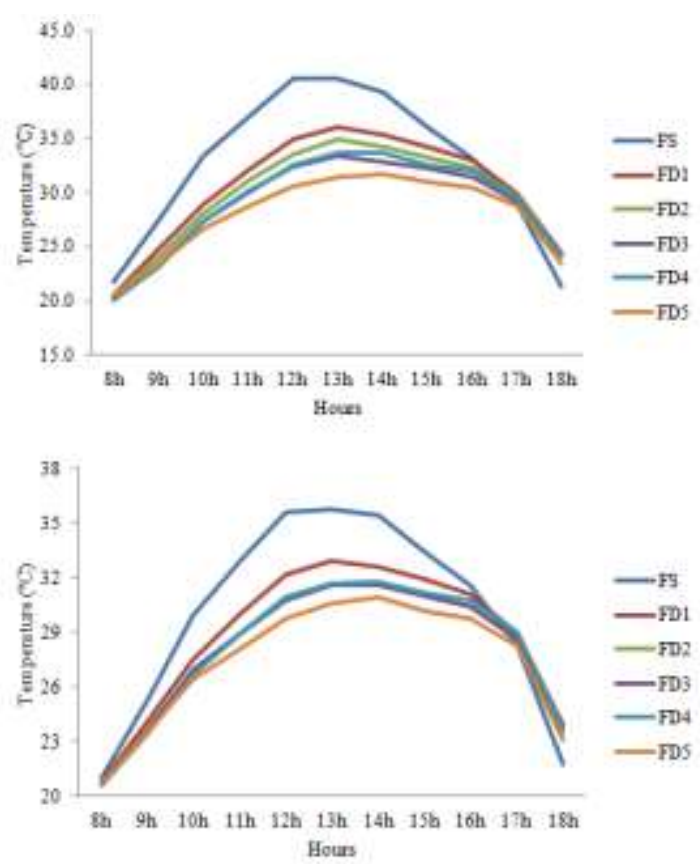

Figure 2 Internal surface temperature (IST) (a) and internal prototype temperature (IT) (b) at the different treatments throughout the day. 
It was observed that the IT behavior was directly linked to IST, i.e. the higher internal surface temperature, the greater the internal temperature of the prototype. This result shows the importance of increasing the roofs' thermal insulation, being according to D'Orazio et al (2010), the increase of roof insulation reduces the costs of artificial cooling inside the buildings. The smaller IT and IST variation, in the treatments where were used double layers, showed the efficiency of this technique in the thermal variation reduction during the day.

The behavior of IT and IST can be seen in Figure 2. The lowest temperature variation throughout the day is desirable for the automation of the environmental control system. In this case, the system will start a smaller number of times, reducing energy expenses (Baêta e Souza 2010).

\section{Conclusions}

The use of metallic and fiber cement covers installed in double-layers $(5 \mathrm{~cm})$ showed a good alternative, with lower prototype internal temperatures (IT) and lower inner surface temperatures (IST) during the warmest hours of the day, and also decreases the temperature variation during the day, promoting a more comfortable environment.

\section{Acknowledgements}

The authors are grateful to São Paulo State Research Foundation (FAPESP) for the financial support provided (Process number 2011/16578-6).

\section{References}

Abreu PG, Abreu VMN, Coldebella A, Jaenisch FRF, Paiva DP (2007) Condições térmicas ambientais e desempenho de aves criadas em aviários com e sem o uso do forro. Arquivo Brasileiro de Medicina Veterinária e Zootecnia 59: 1014-1020.

Abreu PG, Abreu VMN, Coldebella A, Lopes LS, Conceição V, Tomazelli IL (2011) Análise termográfica da temperatura superficial de telhas. Revista Brasileira de Engenharia Agrícola e Ambiental 15: 1193-1198.

Akbari H, Levinson R, Rainer L (2005) Monitoring the energy-use effects of cool roofs on california commercial buildings. Energy and Buildings 37:1007-1016.

Almeida, EA, Passini, R (2013) Thermal comfort in reduced models of broilers' houses, under different types of roofing materials. Engenharia Agrícola 33: 19-27.

Baêta, FC, Souza CF (2010) Ambiência em Edificações Rurais Conforto Animal. UFV, Viçosa.

Caneppele LB, Nogueira MCJA, Vasconcellos AB (2013) Avaliação da eficiência energética e custo benefício no uso de coberturas metálicas em supermercados empregando o software energyplus. Revista eletrônica em gestão, educação e tecnologia ambiental 9: 1971-1979.

Conceição MN (2008) Avaliação da influência do sombreamento artificial no desenvolvimento de novilhas leiteiras em pastagens. Thesis, Universidade de São Paulo.
Curtis, SE. (1983) Environmental management in animal agriculture. Lowa State University Press, Lowa City.

D'orazio M, Di pernax C, Di giuseppea E (2010) The effects of roof covering on the thermal performance of highly insulated roofs in Mediterranean. Climates Energy and Buildings 42:1619-1627.

Damasceno, FA (2008) Avaliação de telhas ecológicas e sua influência no ambiente térmico de modelos físicos de galpões avícolas. Monograph, Universidade Federal de Lavras.

Dias, AS (2011) Avaliação do desempenho térmico de coberturas metálicas utilizadas em edificações estruturadas em aço. Dissertation, Universidade Federal de Ouro Preto.

Faghih AK, Bahadori MN. (2010) Three dimensional numerical investigation of air flow over domed roofs. Journal of Wind Engineering and Industrial Aerodynamics 98: 161-168.

Fiorelli J, Schmidt R, Kawabata CY, Oliveira CEL, Savastano junior H, Rossignolo JA (2012) Eficiência térmica de telhas onduladas de fibrocimento aplicadas em abrigos individuais para bezerros expostos ao sol e à sombra. Ciência Rural 42: 64-67.

Fonseca PCF, Almeida EA. Passini R (2011) Thermal comfort indices in individual shelters for dairy calves with different types of roofs. Engenharia Agrícola 31: 1044-1051.

Fouad AM., Chen W, Ruan D, Wang S, Xia WG, Zheng CT (2016) Impact of Heat Stress on Meat, Egg Quality, Immunity and Fertility in Poultry and Nutritional Factors That Overcome These Effects: A Review. International Journal of Poultry Science 15: 81-95.

Guimarães MCC, Furtado DA, Nascimento JWB, Tota LCA, Silva CM, Lopes KBP (2014) Efeito da estação do ano sobre o desempenho produtivo de codornas no semiárido paraibano. Revista Brasileira de Engenharia Agrícola e Ambiental 18: 231-237.

Michels C (2007) Análise da transferência de calor em coberturas com barreiras radiantes. Dissertation, Universidade Federal de Santa Catarina.

Sampaio CAP, Cardoso CO, Souza GP (2011) Temperaturas superficiais de telhas e sua relação com o ambiente térmico. Engenharia Agrícola 31: 230-236.

Silva KCP, Campos AT, Yanagi Junior T, Cecchin D, Lourençoni D, Ferreira JC (2015) Reaproveitamento de resíduos de embalagens tetra pak ${ }^{\circledR}$ em coberturas. Revista brasileira de engenharia agrícola e ambienta, 19: 58-63.

Song J, K. Xiao K, Ke YL, Jiao LF, Hu CH, Diao QY, Shi B, Zou XT (2014) Effect of a probiotic mixture on intestinal microflora, morphology, and barrier integrity of broilers subjected to heat stress. Poultry Science 93: 581-588.

Tan GY, Yang L, Y. Q. Fu YQ, Feng JH, Zhang MH (2010) Effects of different acute high ambient temperatures on function of hepatic mitochondrial respiration, antioxidative enzymes, and oxidative injury in broiler chickens. Poultry Science 89: 115-22.

Wang RH, Liang RR, Lin H, Zhu LX, Zhang YM, Mao YW, Dong PC, Niu LB, Zhang MH, Luo X (2016) Effect of acute heat stress and slaughter processing on poultry meat quality and postmortem carbohydrate metabolism. Poultry Science 96: 738-746. 